\title{
Development of a new analytical method for determination of acetylsalicylic and salicylic acids in tablets by reversed phase liquid chromatography
}

\author{
José Luiz Neves de Aguiar*, Katia Christina Leandro, \\ Shirley de Mello Pereira Abrantes, André Luis Mazzei Albert
}

Department of Chemistry, National Institute for Health Quality Control, Oswaldo Cruz Foundation

\begin{abstract}
Acetylsalicylic acid (AAS) is a drug utilized as analgesic, anti-inflammatory, and antipyretic medication, available worldwide and commonly used in Brazil. Salicylic acid (AS) is a precursor in AAS synthesis and is also produced during its degradation. The official United States Pharmacopoeia (USP) suggests the determination of these drugs by high performance liquid chromatography (HPLC), with ultraviolet detection, but this method has neither a high sensitivity $\left(\mathrm{S}_{\mathrm{AAS}}=0.12 \mathrm{mAbs} /(\mu \mathrm{g} / \mathrm{mL})\right.$ and $\mathrm{S}_{\mathrm{AS}}=0.48 \mathrm{mAbs} /$ $(\mu \mathrm{g} / \mathrm{mL}))$ nor resolution $(\mathrm{Rs}=1.61)$. The purpose of this study was to develop a new more adequate, accurate method by liquid phase chromatography than the current official methodology, and to use this new method in the determination of the tenors of acetylsalicylic, as of salicylic acids in tablets. The parameters of the chromatographic system for both the AAS and AS were satisfactory. Selectivity was verified by absorption spectra comparison in the ultraviolet (UV) range, during and after substance retention time. The linear range for AAS was 0.21 to $0.39 \mathrm{mg} / \mathrm{mL}$, and that for AS was 6.3 to $11.7 \mu \mathrm{g} / \mathrm{mL}$. The correlation coefficients (r) of the analytical curves of AAS and AS were 0.9995 and 0.9988 , respectively; and the detection and quantification limits for the AS were 0.23 and $0.69 \mu \mathrm{g} / \mathrm{mL}$. The sensitivity $\left(\mathrm{S}_{\mathrm{AAS}}=1.88 \mathrm{mAbs} /(\mu \mathrm{g} / \mathrm{mL})\right.$ and $\left.\mathrm{S}_{\mathrm{AS}}=1.84 \mathrm{mAbs} /(\mu \mathrm{g} / \mathrm{mL})\right)$ and the resolution $(\mathrm{Rs}=5.06)$ show the improvement obtained using this method over that described by the USP.
\end{abstract}

Uniterms: High performance liquid chromatography. Acetylsalicylic acid/determination in tablets. Salicylic acid/determination in tablets. Tablets/quantitative analysis.

O ácido acetilsalicílico (AAS) é um fármaco utilizado como analgésico, antiinflamatório, antipirético, sendo amplamente comercializado e consumido no Brasil e no mundo. Como precursor de sua síntese utiliza-se o ácido salicílico (AS) que também é produzido através de sua degradação. A metodologia oficial da Farmacopéia Americana (USP) preconiza a determinação destes fármacos por cromatografia líquida de alta eficiência (CLAE) com detecção por ultravioleta, mas este método não possui boa sensibilidade $\left(\mathrm{S}_{\mathrm{AAS}}=0,12 \mathrm{mAbs} /(\mu \mathrm{g} / \mathrm{mL})\right.$ e $\left.\mathrm{S}_{\mathrm{AS}}=0,48 \mathrm{mAbs} /(\mu \mathrm{g} / \mathrm{mL})\right)$ e resolução $(\mathrm{Rs}=1,61)$. O objetivo deste trabalho, visando a melhor adequação do sistema cromatográfico em relação à metodologia oficial, foi o desenvolvimento e otimização de um novo método por cromatografia em fase líquida para determinar os teores tanto do ácido acetilsalicílico quanto do salicílico em comprimidos. Os parâmetros da adequação do sistema cromatográfico para o AAS e para o AS foram satisfatórios. A seletividade foi verificada por comparações dos espectros de absorção no ultravioleta (UV) antes, durante e depois do tempo de retenção da substância. A faixa linear de trabalho para o AAS foi de 0,21 a $0,39 \mathrm{mg} / \mathrm{mL}$ e a do AS foi de 6,3 a $11,7 \mu \mathrm{g} / \mathrm{mL}$. Os coeficientes de correlação (r) das curvas analíticas do AAS e do AS foram de 0,9995 e 0,9988 , respectivamente e os limites de detecção e quantificação para o AS foram 0,23 e $0,69 \mu \mathrm{g} / \mathrm{mL}$. A sensibilidade $\left(\mathrm{S}_{\mathrm{AAS}}=1,88 \mathrm{mAbs} /(\mu \mathrm{g} / \mathrm{mL})\right.$ e $\left.\mathrm{S}_{\mathrm{As}}=1,84 \mathrm{mAbs} /(\mu \mathrm{g} / \mathrm{mL})\right)$ e a resolução $(\mathrm{Rs}=5,06)$ atestam a melhoria em relação ao método descrito na USP.

Unitermos: Cromatografia líquida de alta eficiência. Ácido acetilsalicílico/determinação em comprimidos. Ácido salicílico/determinação em comprimidos. Comprimidos/análise quantitativa.

\footnotetext{
*Correspondence: J. L. N. de Aguiar. Departamento de Química, Instituto Nacional de Controle de Qualidade em Saúde, Fundação Oswaldo Cruz, Avenida Brasil, 4365-Manguinhos, 21045-900 - Rio de Janeiro - RJ, Brasil. E-mail:

jose.aguiar@incqs.fiocruz.br
} 


\section{INTRODUCTION}

Acetylsalicylic acid (Figure 1a), also known as aspirin, is the most popular drug worldwide. Every year, $50,000,000,000$ ( 50 billion) tablets of aspirin are sold worldwide, and this does not include other forms of acetylsalicylic acid commonly found in the market, such as other aspirin preparations or associated with other components, such as caffeine or vitamin C. Salicylic acid (Figure 1b), a precursor and also a degradation product of aspirin, is a bifunctional molecule; and can present two types of esterification. In the presence of acetic anhydride, aspirin is formed, whereas in the presence of a methanol excess, the obtained product is methyl salicylate (Wintergreen Oil) (Akre et al., 2001).

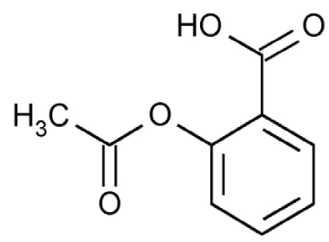

a)

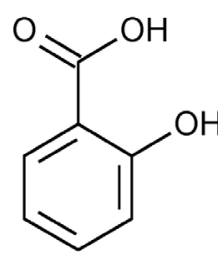

b)
FIGURE 1 - Structural representations of acetylsalicylic acid (1a) and salicylic acid (1b).

The method used by the United States Pharmacopoeia for simultaneous dosing of acetylsalicylic acid and salicylic acid in tablets is that of high performance liquid chromatography (USP 31,2008$)$. The experimental evaluation of this method showed that the parameters for system adequacy (mainly resolution and enlargement factor) did not result in a reliable analysis. This chromatographic system also has a very low sensitivity (INMETRO, 2007), which is undesirable in any quantitative analytical method. Despite several adjustments developed in the mobile phase and the use of several columns of different dimensions, formats and particle diameter, an improvement in the obtained results has not been achieved.

In the development of this new analytical method, the fact that acetylsalicylic and salicylic acids are weak acids, whose ionization constants (pKa) are 3.5 and 3.0; respectively was taken into consideration. Thus, a better methodology to analyze these acids is reversed phase chromatography with ionic suppression of species in solution, through $\mathrm{pH}$ control, and this was applied in the present study.

\section{MATERIAL AND METHODS}

\section{Reagents}

All the solutions were made utilizing ultrapure water of Milli-Q system (Millipore). The following reagents were obtained from Merck (Germany): grade HPLC acetonitrile and analytical grade trifluoroacetic acid.

Standards utilized were acetylsalicylic acid (Reference Chemical Substance of Brazilian Pharmacopoeia) with purity of $100.0 \%$ and salicylic acid (Standard of United States Pharmacopoeia) with purity of $99.4 \%$.

\section{Equipment}

The following equipment was used for this study: Shimadzu liquid phase chromatograph, model SPDM10A, with diode arrangement type photometric detector in the ultraviolet-visible range, and Waters liquid phase chromatograph (model 2487), with photometric detector in the ultraviolet-visible range. The columns used were the Waters reversed phase Novopack, in silica coated with octadecylsilano (C18, $4 \mu \mathrm{m}, 150 \times 3.9 \mathrm{~mm}$ d.i.), and the Merck reversed phase Lichrospher, in silica coated with octadecylsilano (C18, $5 \mu \mathrm{m}, 125$ x $4 \mathrm{~mm}$ d.i.).

\section{Analytical conditions}

Table I presents analytical conditions accepted by United States Pharmacopoeia and the method developed in this study.

\section{Study of degradation kinetic of acetylsalicylic acid}

The degradation kinetic of acetylsalicylic acid was followed by the deacetylation reaction and, consequently, by the salicylic acid formation. A freshly prepared (average preparation time of 25 minutes) solution of acetylsalicylic acid $(0.302 \mathrm{mg} / \mathrm{mL})$ was analyzed 30 consecutive times, and the salicylic acid tenor was determined in every chromatogram under the same analytical conditions using the newly developed method (Table I), in comparison to a standard-solution of salicylic acid $9.0613 \mu \mathrm{g} / \mathrm{mL}$.

\section{Merit parameters evaluation}

The molecular absorption spectra, in the ultraviolet range, of the acetylsalicylic and salicylic acids peaks were obtained in seven levels of the standard addition curve. Spectral comparisons before, during and after the substance characteristic retention time were done to evaluate the selectivity. The work linear range was defined as established in the Guide of Validation of Analytical Methods by the National Health Surveillance Agency [Agência Nacional de Vigilância Sanitária (ANVISA, 2003)]. The first step of the procedure to evaluate the linearity of analytical response for the analyzed substances was done using the 
TABLE I - Analytical conditions of the literature method (USP) and the analytical method developed in this study, with samples injected in Waters and Shimadzu chromatographs

\begin{tabular}{|c|c|c|}
\hline Analytical conditions & Method of USP 31 & Developed method \\
\hline Mobile phase and diluent & $\begin{array}{c}\text { Sodium 1-heptanesulfonate, } \\
\text { water and acetonitrile } \\
\text { (2 g : } 850 \mathrm{~mL}: 150 \mathrm{~mL})(\mathrm{pH} \mathrm{3.4)}\end{array}$ & $\begin{array}{l}\text { acetonitrile : aqueous solution of } \\
\text { trifluoroacetic acid, } 0.05 \%(30: 70)\end{array}$ \\
\hline Detection & $280 \mathrm{~nm}$ & $230 \mathrm{~nm}$ \\
\hline Temperature & $30^{\circ} \mathrm{C}$ & $30^{\circ} \mathrm{C}$ \\
\hline Standard volume & $10 \mu \mathrm{L}$ & $5 \mu \mathrm{L}$ \\
\hline
\end{tabular}

following experimental outline: i) determination of the concentration range of interest, considering the method application. The expected concentrations in the samples were chosen in a way to be close to middle range; ii) preparation of an analytical curve using standard-solutions in seven concentration levels, equally spaced, prepared in triplicate, independent of every level; and iii) random injection of solutions. Data analysis was done with ordinary minimum squares (Souza, Junqueira, 2005). The detection (DL) and quantification (QL) limits for the salicylic acid were evaluated by the signal/noise proportion, which is applicable to instrumental methods presenting basal noise (ANVISA, 2003).

\section{RESULTS AND DISCUSSION}

In accordance with USP 31 methodology (Table I), separate injections of $5 \mu \mathrm{L}$ of acetylsalicylic and salicylic acids standard solutions were done. After determining the retention time of every compound, a solution containing both analyzed substances was injected, in order to evaluate the separation quality. However, the obtained resolution $(\mathrm{Rs}=1.61)$ was not in accordance with the minimal value stated by the FDA or USP 31 of at least two, as the enlargement factor for the acetylsalicylic acid was above the maximum allowed $(<2)$. This system was also shown to give low sensitivity $\left[S_{A A S}=0.12 \mathrm{mAbs} /(\mu \mathrm{g} / \mathrm{mL})\right.$ and $\left.S_{A S}=0.48 \mathrm{mAbs} /(\mu \mathrm{g} / \mathrm{mL})\right]$.

The same standards have been analyzed utilizing the new methodology in this present study (Table I). The parameters of system adequacy, according chromatogram of Figure 2, are presented in Table II (average and variation coefficient of six replicates). The resolution obtained $(\mathrm{Rs}=5.06)$ demonstrates the improvement in the chromatographic separation ability as well as the sensitivity quality, which was 15.7 times superior for acetylsalicylic acid $\left[S_{A A S}=1.88 \mathrm{mAbs} /(\mu \mathrm{g} / \mathrm{mL})\right]$ and 3.8 times superior for salicylic acid $\left[S_{A S}=1.84 \mathrm{mAbs} /(\mu \mathrm{g} / \mathrm{mL})\right]$, in comparison to the method described in the USP. The tail factors lower than 2 demonstrate the peak symmetry. The retention factors are within the range of 1 to 10 , demonstrating the adequate eluent strength of the mobile phase. The number of plates is above the recommended value of 2000 . The repeatability is satisfactory, being below the required value of $2 \%$ (USP $31,2008)$.

TABLE II - Resolution, enlargement factor, retention factor, plate number and repeatability of peak areas of acetylsalicylic and salicylic acids with their respective coefficients of variation $(\mathrm{cv})$

\begin{tabular}{lcc}
\hline $\begin{array}{l}\text { Chromatographic } \\
\text { parameter }\end{array}$ & Acetylsalicylic acid & Salicylic acid \\
\hline Resolution & - & $5.06(\mathrm{cv} \mathrm{0.8 \% )}$ \\
Enlargement factor & $1.20(\mathrm{cv} 1.5 \%)$ & $1.26(\mathrm{cv} 2.0 \%)$ \\
Retention factor & $1.61(\mathrm{cv} 0.2 \%)$ & $2.72(\mathrm{cv} 0.4 \%)$ \\
Plate number & $3080(\mathrm{cv} 0.5 \%)$ & $4177(\mathrm{cv} 1.2 \%)$ \\
Area repeatability & $\mathrm{DPR}^{*}=0.3 \%$ & $\mathrm{DPR}=0.2 \%$ \\
\hline
\end{tabular}

*RSD $=$ Relative Standard Deviation 


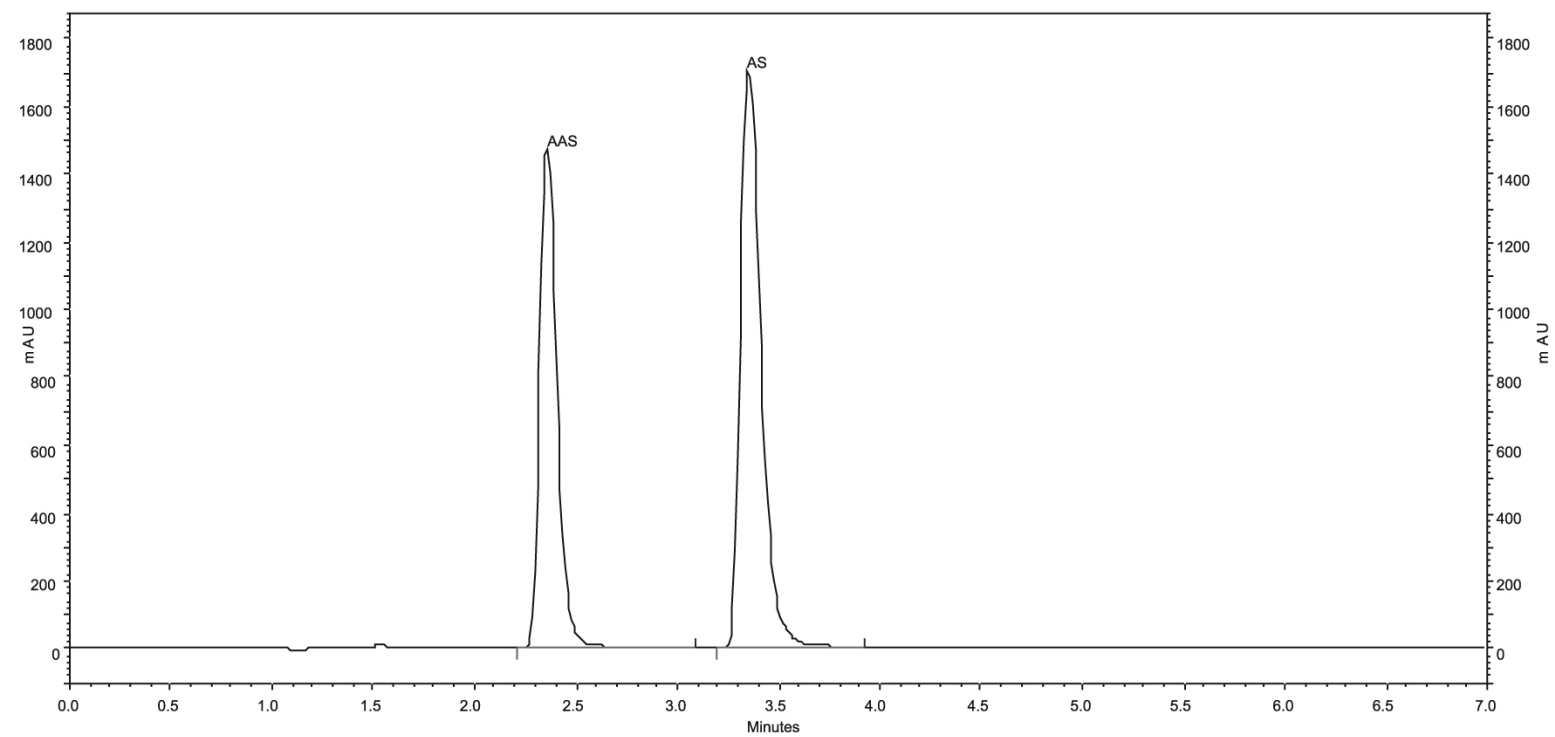

FIGURE 2 - Chromatograms of acetylsalicylic $(0.505 \mathrm{mg} / \mathrm{mL})$ and salicylic acids $(0.511 \mathrm{mg} / \mathrm{mL})$, injected in the Shimadzu chromatograph with DAD*. AAS - retention time: $2.36 \mathrm{~min}$; area: 8998285; plate number: 3191; enlargement factor: 1.21; retention factor: 1.62. AS - retention time: $3.35 \mathrm{~min}$; area: 12441463; plate number: 4341; resolution: 5.36; enlargement factor: 1.44; retention factor: 2.72 .

*DAD $=$ Diode Array Detector

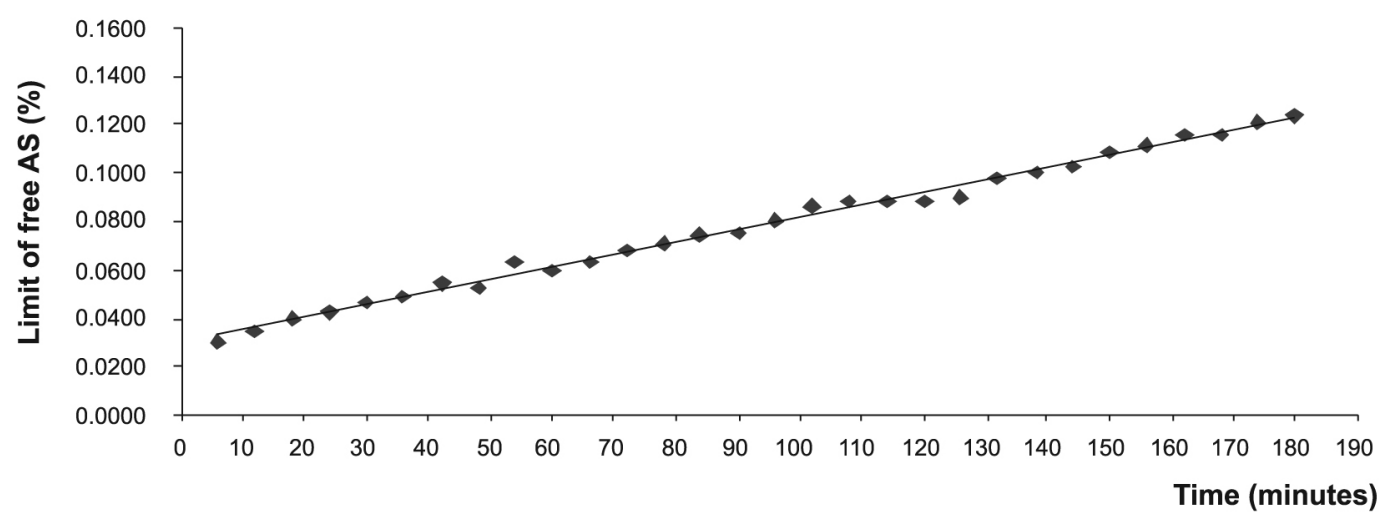

FIGURE 3 - Curve of the kinetic of salicylic acid formation from a standard solution of acetylsalicylic acid $(0.302 \mathrm{mg} / \mathrm{mL})$.

The study of acetylsalicylic acid stability was developed through the analysis of a standard solution of $0.302 \mathrm{mg} / \mathrm{mL}$, during a period of 180 minutes, by liquid chromatography with detection in ultraviolet range, being verified as a linear trend in formation of salicylic acid, tenor $(\%)=0.0005 t+0.0302, \mathrm{R}^{2}=0.9935$ (Figure 3 ). This result implies that, in order to assure the reliability of analytical results in samples that have a salicylic acid tenor which is very close to the tolerated limit (3.0\%), the sample should be injected immediately after its preparation. According to the linear regression equation of the trend to formation of salicylic acid, it is possible to verify that after twenty five minutes (the preparation time of sample), an increase of $0.043 \%$ in the limit of free salicylic acid occurred.
Pureness and selectivity of the peaks of acetylsalicylic and salicylic acids was confirmed through the comparison of spectra of molecular absorption in the ultraviolet range of the substance, against the spectra of molecular absorption in the ultraviolet of the respective standards of acetylsalicylic and salicylic acids.

The linearity of analytical curves of acetylsalicylic acid $\left[\right.$ area $\left.=10^{7}(\mathrm{mg} / \mathrm{mL})-48512, \mathrm{r}=0.9995\right]$ and of salicylic acid $[\operatorname{area}=12663(\mu \mathrm{g} / \mathrm{mL})+1035, \mathrm{r}=0.9988]$ in the studied concentrations range was confirmed and the residue graphics indicated homoscedastic behavior.

The detection and quantification limits determined from the analytical curve of salicylic acid were $0.23 \mu \mathrm{g} / \mathrm{mL}$ and $0.69 \mu \mathrm{g} / \mathrm{mL}$, respectively. 


\section{CONCLUSIONS}

The four adequacy parameters of the chromatographic system for AAS (enlargement factor 1.20; retention factor 1.61; plate number 2485 and relative standard deviation $0.3 \%$ ) and AS (resolution 5.06; enlargement factor 1.26; retention factor 2.72; plate number 4177 and relative standard deviation $0.2 \%$ ) were satisfactory. The selectivity was verified by comparing absorption spectra in UV before, during and after the characteristic time of retention for the substance. The work linear range for AAS was from 0.21 to $0.39 \mathrm{mg} / \mathrm{mL}$ and that for AS was from 6.3 to $11.7 \mu \mathrm{g} / \mathrm{mL}$. The correlation coefficients (r) of the analytical curves of AAS and AS were 0.9995 and 0.9988 , respectively; and the detection and quantification limits for AS were 0.23 and $0.69 \mu \mathrm{g} / \mathrm{mL}$, respectively. The proposed method can thus be employed for the quantitative determination of acetylsalicylic and salicylic acids in tablets, having proved rapid, simple, selective and sensitive.

\section{ACKNOWLEDGEMENTS}

To INCQS*/FIOCRUZ** for the incentive to develop this work.

To my advisor Marcio Labastie, PhD (in memoriam), for his orientation, ideas and encouragement.

*INCQS = Instituto Nacional de Controle de Qualidade em Saúde or National Institute for Health Quality Control

**FIOCRUZ = Fundação Oswaldo Cruz or Oswaldo Cruz Foundation

\section{REFERENCES}

AKRE, K.; EKSTRÖM, A. M.; SIGNORELLO, L. B.; HANSSON, L. -E.; NYRÉN, O. Aspirin and risk for gastric cancer: a population-based case-control study in Sweden. Br. J. Cancer, v.84, p.965-968, 2001.

BRASIL. Agência Nacional de Vigilância Sanitária. R.E.n.899 de 29 de maio de 2003. Guia para validação de métodos analíticos e bioanalíticos. Available at: $<$ http://www.e-legis. brs.br/leis >. Accessed on: 20 mar. 2007.

INMETRO. Orientação sobre validação de métodos de ensaios químicos. Rio de Janeiro: INMETRO, 2007. 24 p. (DOQ CGCRE - 008. Revisão 02).

SOUZA, S. V. C.; JUNQUEIRA, R. G. A procedure to assess linearity by ordinary least squares method. Anal. Chim. Acta, v.552, p.25-35, 2005.

UNITED States Pharmacopeia: USP 31. NF 26. Rockville: United States Pharmacopeia Convention, 2008. p.3000.

Received for publication on $09^{\text {th }}$ September 2008 . Accepted for publication on $07^{\text {th }}$ May 2009. 